\title{
Influence of bovine colostrum thermisation on immunoglobulin intestinal transfer in newborn lambs
}

\author{
J.F. Grongnet ${ }^{1}$, G.T. Dos Santos ${ }^{3}$, M. Piot ${ }^{2}$, R. Toullec ${ }^{1}$ \\ ${ }^{I}$ INRA, Laboratoire du Jeune Ruminant \\ ${ }^{2}$ INRA, Laboratoire de Technologie Laitiére \\ 65 rue de Saint-Brieuc, 35042-RENNES Cedex, France \\ ${ }^{3}$ Université d'Etat de Maringa \\ Parana, Brasil
}

(Received 13 March 1995; accepted 6 November 1995)

\begin{abstract}
ABSTR $\Lambda$ CT
Experiment was carried out to test the influence of mixed bovine colostrum thermisation on immunoglobulin intestinal absorption in newborn lambs. Thirty-three newborn lambs were alloted to three treatments: free maternal suckling or three meals of pooled bovine colostrum $(30 / \mathrm{kg} \mathrm{BW})$, given $0.5,3.5$ and $6.5 \mathrm{~h}$ after birth or three meals of the same but previously heated bovine colostrum. Gentle thermal treatment $\left(62^{\circ} \mathrm{C}\right.$ for $1 \mathrm{~min}$.) was used in order to preserve immunoglobulin biological activity. Immunoglobulin $\mathrm{G}$ levels determined in blood samples collected $3.5,6.5,9.5$ and $12.5 \mathrm{~h}$ after birth were satisfactory but lower in animals receiving bovine colostrum. Thermisation resulted in decreased microbial contamination but did not affect Ig plasmatic levels. In the absence of pathogenic germs, heating colostrum is not necessary to enable an efficient intestinal transfer of immunoglobulin.
\end{abstract}

KEY WORDS: bovine colostrum, newborn lambs, immunoglobulin

\section{INTRODUCTION}

Despite urgent necessity (Levieux, 1984), many newborn ruminants do not have free access to maternal colostrum for several reasons: multiple births, acute mastitis of the dam, inappropriate maternal behaviour, Maedi Visna in the sheep, caprine arthroencephalite virus in the goat, and others. Farmers are aware of the benefit brought by copious ingestion of colostrum containing a high 
proportion of immunoglobulin (Ig) just after birth. That is why, if possible, they often use domestic stocks of colostrum, frozen and mixed. Sheep and goat breeders usually deal with dairy farmers because for several years it has been known that colostrum from different animal species is also effective (Al Jawad and Lees, 1985; Mellor, 1985) in spite of some residual hazards (Winter 1983; Bernadina and Franken, 1985). However, this practice frequently leads to Ig plasma levels below those recorded with maternal suckling or liberal supply of freshly milked colostrum (Stott et al., 1979). Among the reasons referred to, the influence of heavy bacterial contamination may be suspected. First of all, prevailing hygienic "on farm" conditions for collecting, mixing, conserving and final use of colostrum are highly susceptible to strong bacterial contamination. Secondly, Bush and Staley (1980) have suggested that a superabundant normal flora should restrict intestinal transfer of immunoglobulin, even in the absence of pathogenic germs, possibly in hiding particular absorption sites on the membrane of the enterocytes. Aware of the high immunoglobulin thermosensitivity (Trihan, 1986) and without appropriate equipment, farmers hesitate to heat colostrum as immunoglobulin badly treated by rough kitchen cooking could be inactivated.

For these reasons an experiment was carricd out to study the influence of thermisation on denaturation and intestinal transfer of immunoglobulin in bovine colostrum fed to newborn lambs.

\section{MATERIAL AND METHODS}

Thirty-three Charmoise or Rouge de l'Ouest newborn lambs were used. All were born at term and without dystocia from multiparous ewes. All the parturitions occured with one or more persons being present. The animals were divided into three groups: A-12, B-10, C-11, according to body weight, 3.3, 3.5 and $3.2 \mathrm{~kg}$ in group A, B and C, respectively, birth rate and genotype as far as possible. From parturition, ewes and lambs were housed in individual pens, making it easy for the ewes to lick and dry their lambs but preventing suckling except for group $\mathrm{C}$ where free maternal udder access was allowed for only one lamb per mother. The lambs were weighed and their rectal temperature recorded, $0.5,3.5,6.5,9.0$ and $12.5 \mathrm{~h}$ after birth.

Frozen colostrum from about twenty cows was mixed after thawing and then half the quantity was frozen again in portions of one litre volume. The other half was heated on a plate heat-cxchanger at $62^{\circ} \mathrm{C}$ for one minute and then packaged and frozen as for the first half. Three meals of colostrum were given by bottle, at $0.5,3.5,6.5 \mathrm{~h}$ after birth. In case of obvious lack of appetite, oesophageal intubation was carried out. Native colostrum (group B) was given at the rate of 
$30 \mathrm{~g} / \mathrm{kg}$ body weight (BW) but the quantities of heated colostrum (group A) were corrected in order to take into account the apparent immunoglobulin losses occurred during heating. This made it possible to equalize the immunoglobulin amounts received by groups A and B. At 9.5 and $12.5 \mathrm{~h}$, a meal of industrial milk replacer was proposed ( $30 \mathrm{~g} / \mathrm{kg}$ body weight, $20 \mathrm{~g}$ of powder for $80 \mathrm{~g}$ of water). No observation related to suckling was done in group C.

Four blood samples were obtained from the jugular vein, 3.5, 6.5, 9.0 and $12.5 \mathrm{~h}$ after birth before each meal. After recording of hematocrit, the blood was centrifuged and the plasma frozen until determination of IgG concentration by immuno-radial diffusion (Mancini et al., 1965). Colostrum Ig concentrations were measured by HPLC gel-filtration on a Zorbax column and microbial status was evaluated with a routine method (a plate count agar medium for total flora and desoxycholate lactose agar medium for coliforms).

Results were submitted to analysis of variance, $\mathrm{T}$ test or $\mathrm{Chi}^{2}$, when necessary.

\section{RESULTS AND DISCUSSION}

Chemical and microbial characteristics of colostrum are presented in Table1. Colostrum thermisation led to the expected reduction of microbial contamination. Considering the very high initial level (Table 1) and the very gentle heat treatment, a final level of 320000 germs $/ \mathrm{ml}$ should be considered satisfactory. Highly heat-sensitive coliforms were almost totally eliminated. No pathogenic germs were detected before or after heat treatment. Initial Ig colostral level was $46.0 \mathrm{~g} / 1$ which is normal for first milking colostrum issued from high producing Holstein cows (Besser et al., 1991, Pritchett et al., 1991). After treatment, the Ig level fell to $41.5 \mathrm{~g} / \mathrm{l}$. Therefore, Ig destruction due to heat treatment was $4.5 \mathrm{~g} / 1(9.8 \%)$ which is little when compared to the obtaincd microbiological reduction.

TABLE 1

Biochemical and microbial characteristics of bovine colostrum

\begin{tabular}{lcc}
\hline & \multicolumn{2}{c}{ Colostrum } \\
& non-heated (B) & heated (A) \\
\hline IgG, g/l & 46.0 & 41.5 \\
Total germs, $\mathrm{n} / \mathrm{ml}$ & 7000000 & 320000 \\
Colitorms, $\mathrm{n} / \mathrm{ml}$ & 530000 & 3 \\
\hline
\end{tabular}

Appetite for native or heated colostrum was good, except for the second meal and did not differ between the groups (Table 2). Evolution of rectal temperature was almost the same within the three groups (Table 3). No significant drop was 
TABLE 2

Birth weight and appetence of newborn lambs fed bovine colostrum or suckled

\begin{tabular}{lcccc}
\hline & \multicolumn{2}{c}{ Colostrum } & Maternal & Statistical \\
& non-heated $(\mathrm{B})$ & heated $(\mathrm{A})$ & suckling $(\mathrm{C})$ & analysis \\
\hline $\mathbf{n}$ & 10 & 12 & 11 & \\
Birth weight, $\mathrm{kg}( \pm \mathrm{SE})$ & $3.3 \pm 0.64$ & $3.3 \pm 0.83$ & $3.2 \pm 0.64$ & $\mathrm{~ns}^{\prime}$ \\
Number of forced feeding & & & & \\
- first meal, 0.5 h after birth & 1 & 1 & & $\mathrm{~ns}^{2}$ \\
- second meal, 3.5 h after birth & 2 & 3 & & $\mathrm{~ns}^{2}$ \\
- third meal, 6.5 h after birth & 0 & 1 & & $\mathrm{~ns}^{2}$ \\
\hline
\end{tabular}

${ }^{1}$ ANOVA

${ }^{2} \mathrm{Chi}^{2}$

TABLE 3

Rectal temperature of newborn lambs fed bovine colostrum or suckled, ${ }^{\circ} \mathrm{C}( \pm \mathrm{SE})$

\begin{tabular}{lcccc}
\hline \multirow{2}{*}{ Time after birth, h } & \multicolumn{2}{c}{ Colostrum } & Maternal & Statistical \\
& non-heated (B) & hcated (A) & suckling (C) & analysis \\
\hline 0.5 & $39.6 \pm 0.4$ & $38.9 \pm 0.8$ & $39.5 \pm 0.6$ & $\mathrm{~ns}^{\prime}$ \\
3.5 & $39.4 \pm 0.3$ & $38.7 \pm 0.6$ & $39.3 \pm 0.5$ & $\mathrm{~ns}^{\prime}$ \\
6.5 & $39.0 \pm 0.4$ & $39.0 \pm 0.4$ & $39.4 \pm 0.5$ & $\mathrm{~ns}^{\prime}$ \\
9.5 & $39.0 \pm 0.4$ & $38.9 \pm 0.3$ & $39.3 \pm 0.5$ & $\mathrm{~ns}^{1}$ \\
12.5 & $39.1 \pm 0.4$ & $38.9 \pm 0.4$ & $39.4 \pm 0.3$ & $\mathrm{~ns}^{1}$ \\
\hline
\end{tabular}

${ }^{\mathrm{I}}$ ANOVA

recorded in the animals fed bovine colostrum, which indicate that the energy supply of such a diet was correct. The hematocrit (Table 4) was generally decreasing with time, which is in agreement with Grongnet (1986). Even if it is rare, rapid anaemia is always to be feared when newborn lambs receive bovine colostrum (Winter, 1983; Bernadina and Franken, 1985). This did not happen in any of the three groups, as proved by similar hematocrit evolution during the observation period. Further practical observation (survival rate and growth) demonstrated that anaemia did not appear later or was too slight to be of any consequence.

The IgG levels in lambs (Tabel 5) fed native or heated bovine colostrum are similar and satisfactory according to Dos Santos (1987). Therefore, heat treatment did not improve an already efficient physiological process. However, plasmatic IgG levels in lambs given bovine colostrum were finally $33 \%$ lower than those recorded with maternal suckling, $34.6 \mathrm{~g} / \mathrm{l}$, a level which is very high. 
TABLE 4

Hematocrit of newborn lambs fed bovine colostrum or suckled, \% ( $\pm \mathrm{SE})$

\begin{tabular}{lcccc}
\hline \multirow{2}{*}{ Time after bitrh, h } & \multicolumn{2}{c}{ Colostrum } & Maternal & Statistical \\
& non-heated (B) & heated (A) & suckling (C) & analysis \\
\hline 3.5 & $45.5 \pm 4.1$ & $44.5 \pm 4.4$ & 48.1 & $\mathrm{~ns}^{1}$ \\
6.5 & $42.8 \pm 3.8$ & $42.6 \pm 4.8$ & 46.4 & $\mathrm{~ns}^{1}$ \\
9.5 & $40.4 \pm 4.1$ & $39.8 \pm 4.3$ & 43.3 & $\mathrm{~ns}^{1}$ \\
12.5 & $39.7 \pm 4.5$ & $37.3 \pm 4.1$ & 42.2 & $\mathrm{~ns}^{1}$ \\
\hline
\end{tabular}

${ }^{1}$ ANOVA

This result could be related to a more abundant ingestion during suckling and, in addition, ovine colostrum may be richer in immunoglobulin: $60 \mathrm{~g} / \mathrm{l}$ on average (Serieys, 1993). Colostrum ingestion lasted until the end of the experiment in group C while it was stopped at $6.5 \mathrm{~h}$ after birth in groups A and B. Nevertheless, most of the difference between maternal suckling and bovine colostrum feeding was already established $6.5 \mathrm{~h}$ after birth ( $38 \%$ above) and increased only slightly subsequently. This suggests that Ig concentration of maternal colostrum or efficiency of intestinal transfer decreases very quickly after parturition.

TABLE 5

IgG plasmatic levels of newborn lambs fed bovine colostrum or suckled, g/

\begin{tabular}{|c|c|c|c|c|c|}
\hline \multirow{2}{*}{$\begin{array}{l}\text { Time after } \\
\text { birth, } h\end{array}$} & \multicolumn{2}{|c|}{ Colostrum } & \multirow{2}{*}{$\begin{array}{l}\text { Maternal } \\
\text { suckling } \\
\left(\mathrm{x}_{2} \pm \mathrm{SE}\right)\end{array}$} & \multirow{2}{*}{$\frac{2 x_{3} \times 100}{x_{1}+x_{2}}$} & \multirow{2}{*}{$\begin{array}{c}\text { Statictical } \\
\text { analysis }\end{array}$} \\
\hline & $\begin{array}{c}\text { non-heated (B) } \\
\left(x_{1} \pm S E\right)\end{array}$ & $\begin{array}{c}\text { heated (A) } \\
\left(\mathrm{x}_{2} \pm \mathrm{SE}\right)\end{array}$ & & & \\
\hline 3.5 & $6.4 \pm 3.4$ & $5.5 \pm 2.9$ & $5.0 \pm 6.5$ & 84 & ns (ANOVA) \\
\hline 6.5 & $14.0 \pm 3.8$ & $14.4 \pm 6.0$ & $19.6 \pm 11.2$ & 138 & ns (ANOVA) \\
\hline 9.5 & $19.4^{a} \pm 5.0$ & $22.4^{\mathrm{ab}} \pm 5.0$ & $29.4^{\mathrm{h}} \pm 12.4$ & 141 & $P<0.05$ (t test) \\
\hline 12.5 & $23.2^{\mathrm{a}} \pm 5.3$ & $22.7^{\mathrm{a}} \pm 7.8$ & $34.6^{b} \pm 11.9$ & 151 & $\mathrm{P}<0.05$ (t lest) \\
\hline
\end{tabular}

$\mathrm{a}, \mathrm{b}-\mathrm{P}<0.05$

Carefully operated with well adapted equipment, colostrum heating enables elimination of most microbial contaminants while saving a great part of the immunoglobulins. It is therefore a really salutary hygienic practice. On the other hand, destruction of indifferent germs is not needed for good intestinal transfer since, in the case of this experiment, no difference between native and heat treated colostrum was found as far as IgG plasma levels are concerned. If mixed and thawed colostrum or dried colostrum products (for instance semi-purified immunoglobulin) are characterized by low intestinal transfer (Grongnet et al. $1986,1995)$, the reason cannot be normal flora even if it is superabundant. Destruction or removal during processing of a specific absorption factor should be further taken into consideration. 


\section{CONCLUSION}

When maternal suckling is impossible, feeding of lambs with good bovine colostrum should be recommended. It can lead to satisfactory IgG plasma levels, sufficient to protect the newborn efficiently. Mixing several bovine colostra makes the operations more complicated but prevents the rare but real hazard of severe anaemia. If absence of pathogenic germs is certain, heat treatment is not necessary.

\section{REFERENCES}

Al-Jawad A.B., Lees J.L., 1985. Effects of ewe's colostrum and various substitutes on the serum immunoglobulin concentration, gut closure process and growth rate of lambs. Anim. Prod. 40, $123-127$

Bernadina W.E., Franken P., 1983. Feeding cows colostrum to lambs. Vet. Rec. 113, 47-48

Besser T.E., Gay C.C., Pritchett I.., 1991. Comparison of three methods of feeding colostrum to dairy calves. JAVMA 198, 419-422

Bush L.J., Staley T.E., 1980. Absorption of colostral immunoglobulins in newborn calves. J. Dairy Sci. $63,672-680$

Dos Santos G.T., 1987. Quelques aspects physiologiques et nutritionnels de l'adaptation du ruminant nouveau-né à la naissance: absorption des immunoglobulines extraites du colostrum bovin et perturbations digestives, metaboliques et hormonales provoquees par l'hypoxic. $\mathrm{PhD}$ Thesis, Rennes, France, pp. 212

Grongnet J.F., 1984. Metabolic consequences of induced hypoxia in newborn lambs. Ann. Rech. Vet. $15,17-28$

Grongnet J.F., Grongnet-Pinchon E., Levieux D., Piot M., Lareynie J., 1986. Newborn calf intestinal absorption of immunoglobulins extracted from colostrum. Reprod. Nutr. Develop. 26, 731-743

Grongnet J.F., Dos Santos G.T., Piol M., Toullec R., 1995. Influence of some food additives, on IgG plasmatic levels in newborn calves fed a solution of immunoglobulin industrially extracted from colostrum. (In press)

Levieux D., 1984. Transmision de l'immunité passive colostrale: le point des conaissances. In: R. Jarrige (Fditor), Physiologie et Pathologie Périnatales des Animaux de Ferme, INRA, Paris, pp. 116-121

Mancini G., Carbonara A.0., Heremans J.H., 1965. Immunochemical quantitation of antigens by single radial-immunodiffusion. Immunochemistry 2, 235-259

Mellor D.J., 1985. Feeding bovine colostrum to lambs. Vet. Rec. 117, 673-674

Pritchett L.C., Gay C.C., Besser T.E., Hancock D.D., 1991. Management and production factors influencing immunoglobulin Gl concentration in colostrum from Holstein cows. J. Dairy Sci. $74,2336-2341$

Serieys F., 1993. Le Colostrum de Vache. SnithKline Beecham, Ploufragan, France, pp. 88

Stott G.H., Marx D.B., Menefee B.E., Nightengale G.T., 1979. Colostrum immunoglobulin transfer in calves. IV. Effect of suckling. J. Dairy Sci. 62, 1908-1913

Trihan C.. 1986. Valorisation du colostrum bovin et absorption des immunoglobulines par l'agneau. Mémoire de fin d'études ESITPA, Val de Reuil, France, pp. 103

Winter A.C., 1983. Feeding bovine colostrum to newborn lambs. Vet. Rec. 113, 308-309 


\section{STRESZCZENIF}

Wplyw ogrzewania siary bydlęcej na wchlanianie immunoglobulin u nowo narodzonych jagniąt

Doświadczenie przeprowadzono na 33 nowo narodzonych jagniętach podzielonych na trzy grupy: jagnięta, którym podawano zebraną wčeśniej siarę bydlęcą, bez obróbki termicznej, w ilości $30 \mathrm{~g} / \mathrm{kg}$ masy ciała, w $0,5,3,5 \mathrm{i} 6,5$ godzin po urodzeniu: jagnięta, którym podano siarę bydlęcą w analogiczny sposób jak w poprzedniej grupie ale poddaną łagodnemu działaniu temperatury $\left(62^{\circ}\right.$ w ciągu 1 minuty), tak, aby zmnicjszyć skażenie bakteryjne ale zachować biologiczną aktywność immunoglobuliny. Poziom imunoglobuliny $G$ we krwi pobranej od jagniąt w 3,$5 ; 6,5 ; 9,5$ i 12,5 godzin po urodzeniu w grupach otrzymujących siarę bydlęcą byl zadowalający, ale niższy niż u jagniąt ssących matki.

Ogrzewanie spowodowało zmnicjszcnic skażenia siary baktcriami, ale nic wpłynęło na poziom imunoglobulin we krwi. W prıypadku braku w siarze zarazków chorobotwórczych ogrzewanie jej nie jest konieczne dla umożliwienia wydajnego wchlaniania immunoglobulin. 